\title{
IZRAŽANJE IGRE V POVEZAVI S SESNIM REDOM PRI PUJSKIH KRŠKOPOLJSKE PASME - UVODNA RAZISKAVA
}

\author{
Urška KIRN ${ }^{1}$, Manja ZUPAN ${ }^{2}$
}

Delo je prispelo 13. januarja 2016, sprejeto 23. maja 2016. Received January 13, 2016; accepted May 23, 2016.

\begin{abstract}
Izražanje igre $v$ povezavi s sesnim redom pri pujskih krškopoljske pasme - uvodna raziskava

Cilj študije je bil ugotoviti ali sesni red pujska vpliva na izražanje igre v času laktacije. V boksu s slamo smo opazovali 11 pujskov krškopoljske pasme. Pujski so imeli na voljo dva dodatna predmeta, žogo in vrv. Direktna opazovanja živali so potekala pet tednov, trikrat tedensko $\mathrm{v}$ dveh dnevnih intervalih (7.30-9.30 ure, 11.00-13.00 ure) in v 15 min opazovalnih obdobjih. Četrti dan po prasitvi smo pričeli z beleženjem dogodkov igre (tj igra s predmetom, socialna igra, gibalna igra, igra s svinjo), med tem, ko smo opazovanje sesnega reda pričeli šesti dan po prasitvi. Sesni red smo določili na podlagi fotografskega zapisa mesta sesanja. Pujski, ki so bili v času laktacije težji, so izražali manj gibalne igre. Pri bolj igrivih pujskih je bilo opaziti več igre s svinjo in več igre s predmeti. Pogostost igre je bila večja v opoldanskem času kot dopoldanskem in ni bila odvisna od spola. Glavna ugotovitev je, da se je izražanje igre pri pujskih povečevalo s starostjo, ne glede na sesni red.

Ključne besede: prašiči; pasme; krškopoljski prašič; obnašanje živali; etologija; igra; sesni red
\end{abstract}

\section{UVOD}

Sesanje pri pujskih predstavlja začetek prehranjevanja, s čimer si pujski zagotovijo prve hranljive snovi (Rohde Parfet in Gonyou, 1991). Pujski si izberejo sesek, na katerem največkrat sesajo, s čimer se v gnezdu vzpostavi socialna hierarhija, tj sesni red. Začetna dognanja o sesnem redu (Fraser, 1973) so pokazala, da pujski tekmujejo za prednje seske, ki naj bi bili tanjši, daljši in primernejši za sesanje, med tem ko izsledki novejše študije kažejo, da so najbolj zaželeni osrednji seski, kjer je sesni red najmanj stabilen (Skok in Škorjanc, 2013). Mnenja so si tudi raz-
The relationship between play and teat order in piglets of $\mathrm{Kr}$ škopolje breed - A pilot study

The objective of this study was to determine whether teat order affects piglets' play during lactation. The 11 piglets of Krškopolje breed were observed in a pen with straw. Animals had two additional objects, the ball and the rope. Direct observations lasted 5 weeks, 3 times a week in 2 daily intervals (7.30 am-9.30 am, $11.00 \mathrm{am}-1.00 \mathrm{pm}$ ) with $15 \mathrm{~min}$ of observational periods. Observations of play types (i.e. object -, social -, locomotor play, playing with a sow) started on the 4th day after birth while of teat order, which was determined with the help of photos representing a particular suckling teat, started on the $6^{\text {th }}$ day after birth. Piglets expressed less locomotor play if they were heavier. The ones that were more playful expressed more play with a sow and more object play. Play was higher in the late than early mornings and did not differ across sexes. The most important finding is that play increased with the age irrespective of the teat order.

Key words: pigs; breeds; Krškopolje pig; animal behaviour; ethology; play; teat order

lična pri povezavi med mestom sesanja in telesno maso. Horrell in Bennett (1981) sta bila mnenja, da se pujski z večjo rojstno telesno maso bolj prerivajo za prednje seske, kar naj bi vplivalo tudi na prirast med laktacijo. Zadnja študija te hipoteze ni potrdila (Skok in Škorjanc, 2013). Dejstvo je, da je telesna masa pri prašičih odvisna od različnih dejavnikov, med drugim je povezana tudi $\mathrm{z}$ igro Ugotovljeno je, da so živali, ki izražajo več igre, psihično in fizično bolje pripravljene na stresne situacije, predvsem $\mathrm{v}$ času odstavitve, pri čemer so bili dnevni prirasti pri teh živalih večji in nivo agresije nižji (Donaldson in sod.,

1 Univ. v Ljubljani, Biotehniška fak., Odd. za zootehniko, Groblje 3, SI-1235 Domžale, Slovenija, e-naslov: urskapoljansek@gmail.com

2 Isti naslov kot 1, e-naslov: manja.zupan@bf.uni-lj.si 
2002), telesna masa pa je bila pozitivno povezana $\mathrm{z}$ igro $\mathrm{s}$ predmetom (Zupan in sod., 2016).

Dobro prehranjeni pujski v optimalnih pogojih reje pogosto izražajo igro, kar je pomemben indikator dobrega počutja živali (Newberry in sod., 1988; Lawrence in Appleby, 1996; Held in Špinka, 2011). Živali igro izražajo takrat kadar so zdrave in se počutijo varne ter neogrožene (Špinka in sod., 2001). Preko igre mladiči razvijajo telesno moč, vztrajnost in spretnost (Dobao in sod., 1985). Poznamo igro s predmetom, gibalno in socialno igro ter igro s plenom (Dugatkin, 2009). Pri domačih živalih so ključnega pomena prve tri oblike igre. Igra s predmetom vključuje predmete iz okolja, s katerimi se živali zaposlijo, lahko individualno ali skupinsko. Pogosto je takšen način igre povezan $\mathrm{z}$ raziskovalnim (radovednim) obnašanjem. Gibalna igra je premikanje lastnega telesa iz ene v drugo smer. Mlade živali pogosto oponašajo gibanja, ki zanje še niso smiselna (npr. napad, umik, naskakovanje). Socialna igra je igra s sovrstniki, kjer pride do povezovanja in navezovanja telesnih stikov. Ob tem se živali priučijo taktike obnašanja za uspešne boje s sovrstniki in vzpostavijo čvrste socialne vezi v skupini (Fraser in Broom, 1990). Pujski si $\mathrm{z}$ neškodljivimi medsebojnimi pretepi merijo moči in tako drug drugemu pokažejo, kdo od njih je najmočnejši.

Pri pregledu literature o sesnem redu (tj mestu sesanja) ter izražanju igre pri prašičih ni moč zaslediti podatka ali mesto sesanja vpliva na izražanje igre in posledično na telesno maso. V ta namen smo naredili uvodno študijo, ki je bila predmet diplomskega projekta, katerega cilj je bil ugotoviti, ali obstajajo razlike med pujski v izražanju igre v času laktacije glede na sesni red. To je prva tovrstna študija s področja opazovanja igre pri domačih živalih v Sloveniji. Zanimalo nas je tudi, ali je izražanje igre čez dan enakomerno in ali se povečuje s starostjo. Kaže, da je igra pri pujskih najpogostejša med drugim in šestim tednom starosti ter odvisna od sistema uhlevitve (Newberry in sod., 1988). Igra je $\mathrm{v}$ boksih $\mathrm{z}$ nastiljem najpogostejša $\mathrm{v}$ četrtem tednu, $\mathrm{v}$ boksih $\mathrm{z}$ golimi tlemi pa $\mathrm{v}$ šestem tednu starosti.

\section{MATERIAL IN METODE}

$\mathrm{V}$ poskus je bilo vključenih 11 pujskov krškopoljske pasme, 5 svinjk in 6 kastratov iz istega gnezda. Svinja je bila uhlevljena v boksu velikosti $3,8 \mathrm{~m} \times 4,0 \mathrm{~m} \mathrm{~s}$ polnimi tlemi in nastiljem iz slame. Temperatura hleva $\mathrm{v}$ času trajanja poskusa, merjena $\mathrm{v}$ višini živali, je bila $\mathrm{v}$ povprečju $15,3^{\circ} \mathrm{C}$. Od tretjega tedna naprej so pujski poleg materinega mleka dobivali krmo, ki je bila sestavljena iz namočenega kruha, sladkorja in ekološkega štarterja za pujske. Sveža voda jim je bila na voljo v posodi od prasitve naprej.

Drugi dan po prasitvi smo v boks, $10 \mathrm{~cm}$ od tal, obe- sili igrali, žogo in vrv (slika 1a). Svinja ni imela dostopa do igral. Četrti dan po prasitvi smo začeli zapisovati dogodke igre (tj igra s predmetom (slika 1a), socialna igra (slika 1b), gibalna igra, igra s svinjo), med tem ko smo sesni red začeli opazovati šesti dan po prasitvi. Uporabljen etogram je opisan v preglednici 1. Opazovanja obnašanja je opravil en opazovalec. Opazovanja so trajala pet tednov, trikrat tedensko po štiri ure $\mathrm{z}$ vmesnim odmorom. Opazovanja so potekala direktno in sicer v jutranjem (od 7.30 do 9.30 ure) in opoldanskem času (od 11.00 do 13.00 ure). Intervalno opazovanje je bilo razdeljeno na 8 opazovalnih obdobjih s po 15 min. Posamezno opazovalno obdobje smo razdelili na $30 \mathrm{~s}$ intervale. Pogostost igre smo spremljali kontinuirano, med tem ko smo pogostost sesanja spre-

a)

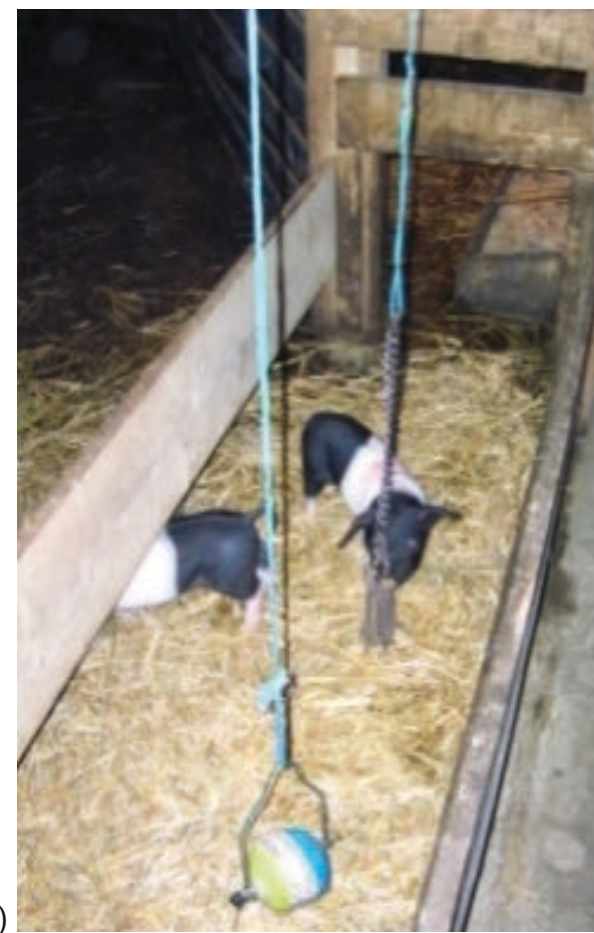

b)

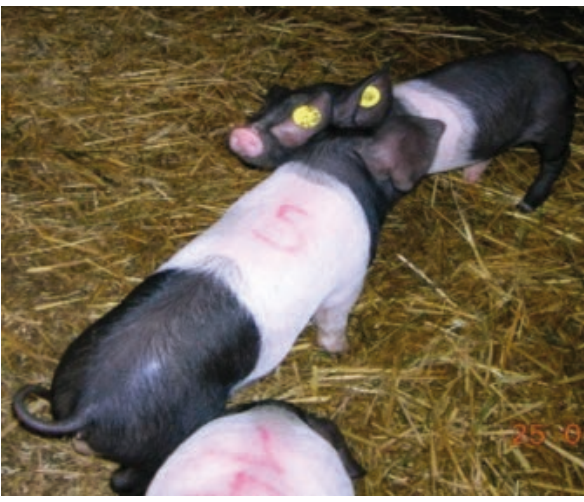

Slika 1: Igra s predmetom (a) ter socialna igra pujskov (b) (Foto: Urška Poljanšek, 2014)

Figure 1: Object play (a) and social play (b) of piglets (Foto: Urška Poljanšek, 2014) 
Preglednica 1: Etogram pujskov v obdobju laktacije

Table 1: The ethogram of piglets during lactation period

\begin{tabular}{|c|c|}
\hline Oblike obnašanja & Opis \\
\hline \multicolumn{2}{|l|}{ Socialna igra } \\
\hline $\begin{array}{l}\text { Vzpenjanje drug na } \\
\text { drugega }\end{array}$ & Pujsek se dvigne s prednjimi nogami na hrbet drugega pujska od zadaj ali s strani. \\
\hline Spoznavanje & $\begin{array}{l}\text { Vključuje žvečenje, grizljanje, sesanje in vse dejavnosti med pujski, ki so usmerjene v telo drugega } \\
\text { pujska, razen v trebuh in rep. Vključuje tudi ugrize, grizljanje, ovohavanje ter dotike nos na nos ali } \\
\text { lice na lice z drugim pujskom po hitrem premikanju glave. Eden od pujskov lahko sedi ali leži. }\end{array}$ \\
\hline Grizenje repov & Grizljanje, žvečenje repov drugih pujskov. \\
\hline Drgnjenje trebuha & $\begin{array}{l}\text { Drgnjenje z glavo gor in dol po trebuhu ali med zadnjima nogama drugega pujska, medtem ko ta } \\
\text { leži. }\end{array}$ \\
\hline Stik z glavo & $\begin{array}{l}\text { Namerno hitro, stransko premikanje glave ob glavo ali telo drugega pujska. Če je vmes } 2 \text { sekundi } \\
\text { premora je to naslednji stik z glavo. }\end{array}$ \\
\hline Dviganje & Uspešno dviganje drugega pujska z glavo izpod trebuha ali zadnjih nog. \\
\hline Igra s svinjo & Vse sesanje, ovohavanje, grizenje, žvečenje usmerjeno v katere koli dele svinje, razen v vime. \\
\hline \multicolumn{2}{|l|}{ Gibalna igra } \\
\hline Skok & Hiter padec iz pokončnega položaja na tla, ki ni posledica zdrsa ali potiskanja drugega pujska. \\
\hline Obrat & Skok z obratom na enem mestu, tako da se telo zavrti vsaj za $90^{\circ}$ vodoravno. \\
\hline Poskakovanje & $\begin{array}{l}\text { Skakanje gor in dol na enem mestu, včasih z obračanjem } \mathrm{v} \text { drugo smer, vendar ne toliko kot pri } \\
\text { obratu, z občasnim premikanjem glave. }\end{array}$ \\
\hline Tekanje sem in tja & $\begin{array}{l}\text { Tekanje v vse smeri, včasih tudi s kretnjami glave in dotiki z drugimi pujski. Opredeli se, ko pujsek } \\
\text { na hitro zamenja smer in nadaljuje gibanje. }\end{array}$ \\
\hline \multicolumn{2}{|l|}{ Igra s predmetom } \\
\hline Slama & Grizenje, žvečenje, prenašanje, ovohavanje, razmetavanje, ritje, zauživanje \\
\hline Žogica & $\begin{array}{l}\text { Manipuliranje žogice z gobcem (grizenje, lizanje, sesanje), dotikanje z glavo ali rilcem (potiskanje ali } \\
\text { vlečenje), držanje žoge v ustih medtem ko se giba naprej ali vstran (vlečenje) ali z žogo v ustih hitro } \\
\text { premikanje glave s strani v stran (tresenje). }\end{array}$ \\
\hline Vrv & $\begin{array}{l}\text { Manipuliranje vrvi z usti (grizenje, lizanje, sesanje), dotikanje vrvi z glavo ali rilcem (potiskanje } \\
\text { ali vlečenje), drži vrv v ustih medtem ko se giba naprej ali vstran (vlečenje) ali z vrvjo v ustih hitro } \\
\text { premikanje glave s strani v stran (tresenje). }\end{array}$ \\
\hline
\end{tabular}

mljali intervalno. Aktivnost sesanja smo beležili tudi v grafični obliki z uporabo fotoaparata. S pomočjo fotografij smo določili mesto sesanja posameznega pujska glede na frekvenco sesanja na posameznem sesku (1-14 sesek; $\mathrm{z}$ desne proti levi, od glave proti repu; pregl. 2). Svinja je imela slepi sesek (deveti sesek). Polno zasedeni so bili prvi (1. in 8. sesek), tretji (3. in 10. sesek), četrti (4. in 11. sesek) in sedmi (7. in 14. sesek) sesni par. Pujske smo v času opazovanj stehtali petkrat, enkrat na teden, na isti dan v tednu. Telesno maso smo izmerili tudi ob rojstvu in ob odstavitvi (39. dan). Povprečna rojstna telesna masa pujskov je bila 1,24 $\pm 0,08 \mathrm{~kg}$, medtem ko je bila odstavitvena telesna masa $8,37 \mathrm{~kg} \pm 1,20 \mathrm{~kg}$.

Za statistično obdelavo podatkov smo uporabili program SAS paket, verzija 9.3 (SAS Institute, 2008). Proceduro UNIVARIATE smo uporabili za pregled razporejenosti podatkov. Za ugotavljanje korelacij med igro skupaj (tj seštevek dogodkov različnih načinov igre) in različnimi oblikami igre ( $\mathrm{n}=4$; gibalna in socialna igra ter igra s predmetom in s svinjo), seskom $(n=14)$, sesnim parom $(n=7)$, rojstno in odstavitveno maso smo uporabili proceduro CORR. Proceduro GLM smo uporabili za ugotavljanje vpliva spola ( $\mathrm{n}=2$; svinjke in kastrati), obdobja starosti ( $n=3$; 1. obdobje: 4.-13. dneva starosti, 2. obdobje: 14.-25. dneva starosti, 3. obdobje: 26.-36. dneva starosti) in dnevno opazovalnega intervala $(n=2$; jutranji in opoldanski) na izražanje posamezne oblike igre in na igro skupaj.

\section{REZULTATI IN DISKUSIJA}

$\mathrm{V}$ naši študiji je bila $\mathrm{v}$ posameznem opazovalnem obdobju najpogostejše izražena oblika igre igra s pred- 
Preglednica 2: Pogostost sesanja na določenem sesku v odstotkih

Table 2: The frequency of suckling on a particular teat in percentages

\begin{tabular}{|c|c|c|c|c|c|c|c|c|c|c|c|c|c|c|}
\hline \multirow[b]{2}{*}{ Pujsek } & \multicolumn{2}{|c|}{ Sesni par 1} & \multicolumn{2}{|c|}{ Sesni par 2} & \multicolumn{2}{|c|}{ Sesni par 3} & \multicolumn{2}{|c|}{ Sesni par 4} & \multicolumn{2}{|c|}{ Sesni par 5} & \multicolumn{2}{|c|}{ Sesni par 6} & \multicolumn{2}{|c|}{ Sesni par 7} \\
\hline & $\begin{array}{l}\text { Sesek } \\
1\end{array}$ & $\begin{array}{l}\text { Sesek } \\
8\end{array}$ & $\begin{array}{l}\text { Sesek } \\
2\end{array}$ & $\begin{array}{l}\text { Sesek } \\
9\end{array}$ & $\begin{array}{l}\text { Sesek } \\
3\end{array}$ & $\begin{array}{l}\text { Sesek } \\
10\end{array}$ & $\begin{array}{l}\text { Sesek } \\
4\end{array}$ & $\begin{array}{l}\text { Sesek } \\
11\end{array}$ & $\begin{array}{l}\text { Sesek } \\
5\end{array}$ & $\begin{array}{l}\text { Sesek } \\
12\end{array}$ & $\begin{array}{l}\text { Sesek } \\
6\end{array}$ & $\begin{array}{l}\text { Sesek } \\
13\end{array}$ & $\begin{array}{l}\text { Sesek } \\
7\end{array}$ & $\begin{array}{l}\text { Sesek } \\
14\end{array}$ \\
\hline 1 & 0,22 & 0,23 & 0,72 & 2,20 & 0,27 & 0,00 & 92,78 & 0,61 & 1,36 & 0,00 & 0,28 & 1,61 & 1,04 & 0,00 \\
\hline 2 & 0,22 & 0,00 & 0,24 & 10,67 & 0,74 & 0,80 & 0,56 & 0,00 & 0,00 & 0,00 & 0,00 & 3,23 & 83,68 & 1,18 \\
\hline 3 & 0,66 & 0,00 & 0,00 & 0,00 & 0,26 & 0,27 & 0,00 & 0,00 & 0,00 & 0,24 & 0,28 & 0,81 & 1,55 & 95,88 \\
\hline 4 & 95,63 & 0,23 & 0,24 & 0,00 & 0,00 & 0,00 & 0,00 & 0,00 & 0,00 & 0,00 & 0,00 & 0,00 & 0,00 & 3,18 \\
\hline 5 & 0,00 & 0,23 & 0,48 & 0,00 & 0,53 & 0,19 & 0,56 & 0,00 & 90,79 & 0,15 & 5,00 & 0,48 & 0,26 & 0,00 \\
\hline 6 & 0,22 & 0,00 & 7,95 & 0,27 & 0,00 & 1,33 & 0,56 & 86,67 & 0,54 & 0,60 & 0,83 & 8,06 & 0,52 & 0,00 \\
\hline 7 & 0,44 & 0,47 & 87,47 & 0,00 & 0,21 & 10,70 & 0,56 & 0,91 & 0,00 & 0,00 & 0,28 & 0,16 & 0,00 & 0,00 \\
\hline 8 & 0,00 & 0,00 & 0,48 & 0,27 & 2,38 & 83,78 & 0,28 & 0,11 & 0,27 & 10,12 & 0,56 & 0,00 & 0,52 & 0,29 \\
\hline 9 & 0,00 & 1,64 & 1,93 & 5,56 & 84,66 & 0,00 & 3,33 & 0,30 & 1,36 & 0,00 & 0,56 & 0,00 & 0,96 & 0,12 \\
\hline 10 & 0,29 & 96,95 & 0,24 & 0,00 & 0,00 & 0,00 & 0,40 & 0,00 & 0,84 & 0,00 & 0,86 & 0,00 & 0,40 & 0,00 \\
\hline 11 & 0,00 & 0,23 & 0,24 & 0,00 & 0,00 & 0,27 & 1,11 & 0,30 & 0,51 & 1,52 & 91,67 & 1,61 & 2,59 & 0,29 \\
\hline
\end{tabular}

metom. Znotraj igre s predmetom se je največkrat pojavila igra s slamo (71,90 \%), ki so jo imeli pujski ves čas na voljo. Rezultat je pričakovan, saj slama služi pujskom za počitek ter kot sredstvo za izražanje pozitivnih čustev ter dobrega počutja (Mansbridge in Stewart, 2012). Pri socialni igri, v vseh opazovanih obdobjih, je bila najbolj izražena oblika spoznavanje (9,20 \%), ki je primer obnašanja, ki služi kot funkcija igre, s pomočjo katere se pujski priučijo taktike obnašanja za uspešne boje s sovrstniki (Fraser in Broom, 1990). Tretja najpogostejša oblika obnašanja je bil stik s svinjo (5,90\%). Opazili smo, da so pujski med sesanjem pustili sesek in šli h glavi svinje medtem, ko je svinja spala, jo ovohavali, grizljali za ušesa, rep in noge in se oglašali. Vloga svinje pri razvoju pujskov ni le v stimulaciji po sesanju (Petersen in sod, 1990), temveč, kot je pokazala naša študija, tudi $v$ splošnem boljšem počutju, saj so živali, ki so bile več v stiku s svinjo, kazale več igre skupaj (pregl. 3). Svinja pozitivno vpliva na razvoj pujskov in s tem pripravlja pujske na boljšo pripravljenost kasneje v življenju, ko so izpostavljeni različnim stresnim dejavnikom. Svinja pujske s svojim telesom varuje (Rosillon-Warnier in Paquay, 1984) in greje (Hrupka in sod., 1998), s čimer ustvarja varno okolje, v katerem lahko izražajo igro. Gibalna igra je bila najmanj izražena oblika igre $(0,30 \%)$. Pri gibalni igri je poraba energije velika, kar je možna utemeljitev za majhno pogostost izražanja.

Preglednica 3: Korelacijski koeficienti (pod sivo črto) in p-vrednosti (nad sivo črto) med sesnim parom, seski, rojstno in odstavitveno telesno maso ter različnimi oblikami igre

Table 3: The correlation coefficients (below gray mark) and P-values (above gray mark) between suckling pair, teats, birth weight, weight at weaning and different play types

\begin{tabular}{|c|c|c|c|c|c|c|c|c|c|}
\hline & Sesni par & Sesek & MasaROJ & MasaODS & SoIGRA & IgraSVI & GibIGRA & PredIGRA & IgraSKU \\
\hline Sesni par & & 0,13 & 0,46 & 0,35 & 0,63 & 0,25 & 0,78 & 0,68 & 0,60 \\
\hline Sesek & 0,49 & & 0,71 & 0,21 & 0,58 & 0,13 & 0,18 & 0,17 & 0,18 \\
\hline MasaROJ & 0,25 & $-0,13$ & & 0,13 & 0,23 & 0,96 & 0,54 & 0,31 & 0,53 \\
\hline MasaODS & 0,32 & $-0,41$ & 0,49 & & 0,94 & 0,10 & 0,03 & 0,14 & 0,11 \\
\hline SoIGRA & 0,16 & 0,19 & 0,40 & 0,02 & & 0,75 & 0,73 & 0,41 & 0,91 \\
\hline IgraSVI & $-0,38$ & $-0,49$ & 0,02 & 0,52 & 0,11 & & 0,14 & 0,07 & 0,01 \\
\hline GibIGRA & $-0,10$ & 0,44 & $-0,21$ & $-0,65$ & 0,12 & $-0,48$ & & 0,51 & 0,54 \\
\hline PredIGRA & $-0,14$ & $-0,45$ & $-0,34$ & 0,48 & $-0,28$ & 0,57 & $-0,22$ & & $<0,0001$ \\
\hline IgraSKU & $-0,18$ & $-0,43$ & $-0,21$ & 0,51 & 0,04 & 0,73 & $-0,21$ & 0,94 & \\
\hline
\end{tabular}

(MasaROJ - rojstna telesna masa, MasaODS - odstavitvena telesna masa, SoIGRA - socialna igra, IgraSVI - igra s svinjo, GibIGRA - gibalna igra, PredIGRA - igra s predmetom, IgraSKU - igra skupaj, vsota vseh načinov igre) 


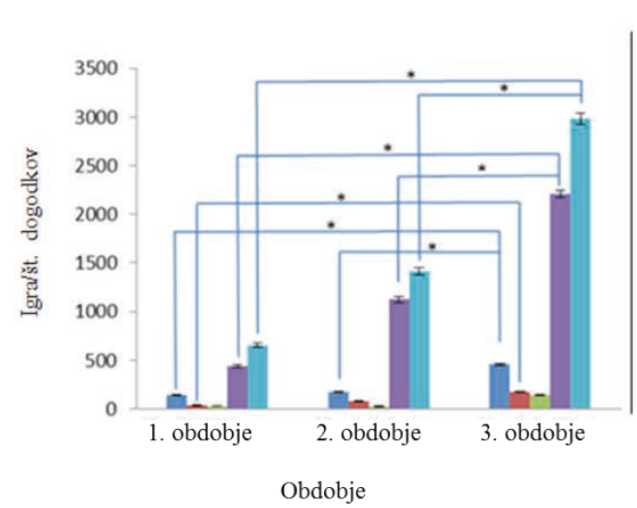

a)

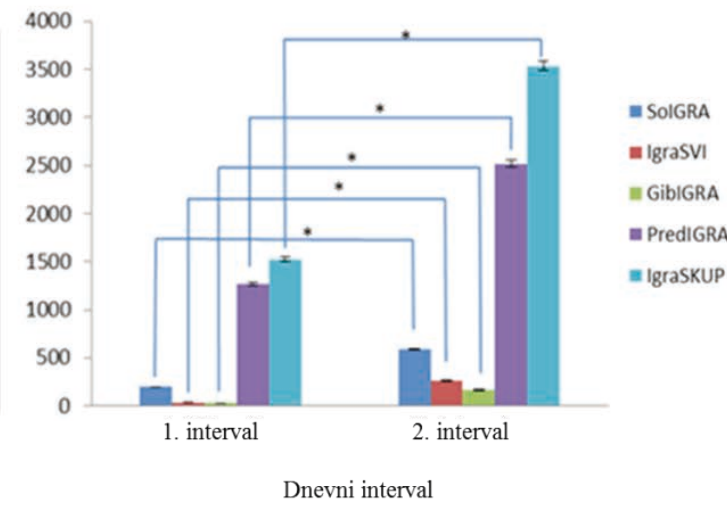

b)

Slika 2: Vpliv časovnega obdobja (a): 1. obdobje: od 4. dneva do 13. dneva starosti; 2. obdobje: od 14. dneva do 25. dneva starosti; 3. obdobje: 26. dneva do 36. dneva starosti ter intervala na izražanja igre (b): 1. interval (od 7.30 do 9.30 ure), 2. interval (od 11.00 do 13.00 ure)

Figure 2: The effect of time period (a): 1. period: from $4^{\text {th }}$ till $13^{\text {th }}$ days of age; 2. period: from $14^{\text {th }}$ till $25^{\text {th }}$ days of age; 3 . period: from $26^{\text {th }}$ till $36^{\text {th }}$ days of age $(b)$ : 1. interval (7.30 am-9.30 am); 2. period (11 am-1 pm)

Podobne rezultate pri prašičih po odstavitvi navaja Rauw (2013).

Med igro skupaj in igro s predmetom je bila ugotovljena pozitivna korelacija (pregl. 3). Obogatitev okolja pri prašičih pomembno vpliva na socialne in motorične lastnosti živali, razvijanje telesne moči, vztrajnosti in spretnosti. To potrjujejo tudi Chaloupková in sod. (2007), ki so mnenja, da lahko dodajanje slame in povečanje prostora pozitivno vpliva na izraženje igre. $\mathrm{V}$ nasprotju $\mathrm{s}$ to študijo in $\mathrm{z}$ našimi rezultati, pa pujski, ki so imeli na voljo predmete, niso izražali več gibalne ali socialne igre kot pujski, ki niso imeli na voljo predmetov
(Hultman, 2012). Negativna korelacija je bila ugotovljena med odstavitveno telesno maso in gibalno igro. To pomeni, da so pujski $\mathrm{z}$ večjo odstavitveno telesno maso izražali manj gibalne igre. Izsledki novejše študije kažejo Zupan in sod. (2016), da je izražanje gibalne igre v povezavi s telesno maso odvisno od tega ali je bil posamezen pujsek v času laktacije taktilno stimuliran ali ne. Rezultat obeh študij ni presenetljiv, saj je na podlagi evolucijskih teorij znano, da je razvoj obnašanja pod vplivom telesne mase (Thelen, 2000).

Med svinjkami in kastrati ni bilo značilnih razlik v izražanju igre skupaj $(\mathrm{df}=1 ; \mathrm{F}=1,01 ; p=0,93)$. Rezultati

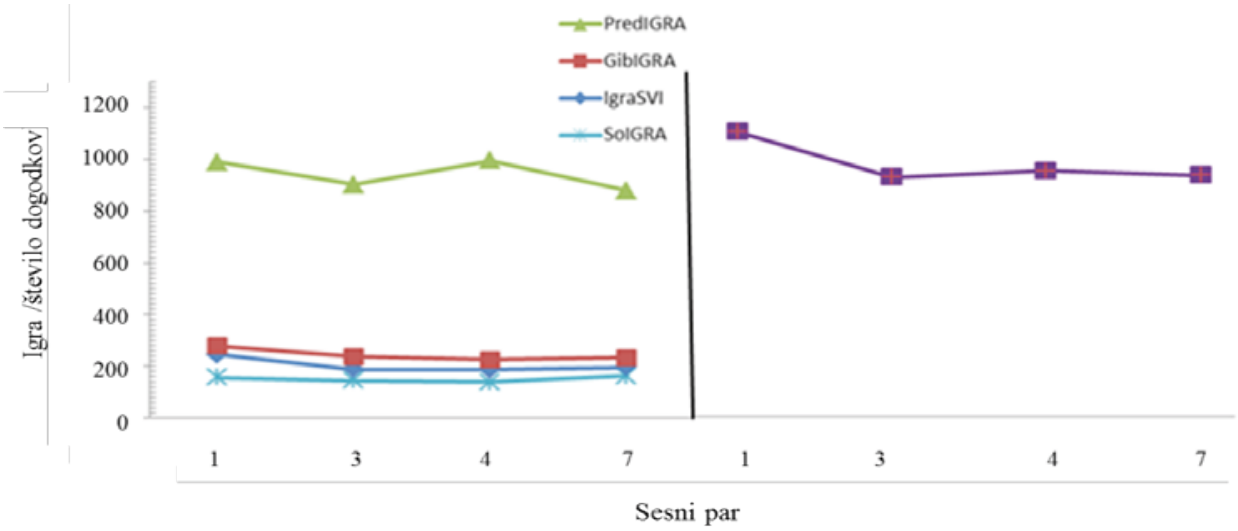

Slika 3: Spreminjanje aktivnosti štirih oblik igre (levo) in igre skupaj (desno) glede na sesni par. Sesni pari so bili označeni od 1 do 7, od sprednjega do zadnjega dela mamalnega kompleksa. PredIGRA - igra s predmetom, GibliGRA - gibalna igra, IgraSVI - igra s svinjo, SolIGRA - socialna igra.

Figure 3: The display of four play types (left) and play total (right) based on teat-pair. The teat-pairs were followed from the front until the back part of the udder. PredIGRA - object play, GiblIGRA - locomotor play, IgraSVI - play with a sow, SolIGRA - social play. 
v literaturi so si nasprotni glede vpliva spola na izražanje igre. Farhadi (2013) navaja, da naj bi ženski osebki izražali več igre s predmetom, medtem ko so Zupan in sod. (2016) ugotovili ravno nasprotno. Nadalje, Zupan in sod. (2016) ter Rauw (2013) so mnenja, da svinjke izražajo več gibalne igre kot kastrati. Starejše študije na prašičih tega ne potrjujejo (socialna igra: Newberry in Wood-Gush, 1986; gibalna igra: Newberry in sod., 1988).

Pujski so kazali več igre skupaj $\mathrm{v}$ opoldanskem času v primerjavi $\mathrm{z}$ dopoldanskim časom (slika $2 \mathrm{~b}$; $\mathrm{df}=$ $1 ; \mathrm{F}=10,69 ; p=0,003)$. Statistično značilne razlike igre med dnevnima intervaloma so bile pri vseh oblikah igre, socialni igri $(\mathrm{df}=1 ; \mathrm{F}=9,50 ; p=0,0048)$, gibalni igri $(\mathrm{df}=1, \mathrm{~F}=5,08 ; p=0,0328)$, igri s predmetom $(\mathrm{df}=1$; $\mathrm{F}=7,28 ; p=0,0121)$ in pri igri s svinjo $(\mathrm{df}=1 ; \mathrm{F}=13,74$; $p=0,0010)$. Razlike med intervaloma, med katerima je bila časovna razlika le eno uro in pol, si lahko razlagamo $\mathrm{z}$ gospodarnostjo reje na kmetiji. $\mathrm{V}$ času jutranjega opazovanja je potekalo krmljenje svinje in tudi pujskov. V hlevu je bilo zato več hrupa, ki bi lahko vplival na obnašanje. V prvem intervalu se skozi ves čas opazovanj nista pojavila grizenje repov in dviganje. Iz tega lahko sklepamo, da pujski med seboj niso izražali agresije, strahu in stresa, ki so znak neugodnih razmer v hlevu in med pujski (Zupan in sod., 2012). Te dve obliki igre sta tudi $\mathrm{v}$ drugem intervalu imeli najmanj opaženih dogodkov (okrog 0,30 \%).

Pogostost posameznih oblik igre je s starostjo naraščala, $\mathrm{z}$ izjemo gibalne igre (slika $2 \mathrm{a}$ ), s tem pa tudi igra skupaj $(\mathrm{F}=10,33 ; p=0,0005)$. Najbolj vidne razlike $\mathrm{v}$ pogostosti igre so bile med prvim (od 4. do 13. dneva starosti) in tretjim obdobjem (od 27. do 36. dneva starosti). Rezultate lahko pojasnimo z dejstvom, da pujski v prvih dneh življenja veliko spijo (tudi do $90 \%$ ), s starostjo pa se čas mirovanja, spanja in sesanja zmanjšuje, medtem ko se povečuje čas aktivnosti (Fraser in Broom, 1990). Pujski so ob rojstvu še zelo šibki in nebogljeni, s starostjo pa pridobivajo na telesni masi in se fizično ter psihično razvijajo. Vse to lahko vodi k povečanju aktivnosti igre proti koncu laktacije. Dodaten vzrok za povečano igrivost na koncu laktacije je v dejstvu, da so pri starosti treh tednov naši pujski začeli žreti koncentrirano krmo, s čimer se je povečala splošna aktivnost. Pujski so si morali pri koritu s krmo izboriti svoj prostor, ki je bil oddaljen od svinje.

$\mathrm{V}$ naši študiji, ki je majhnega obsega, smo ovrgli glavno hipotezo, da obstajajo razlike med sesnim mestom ter sesnim parom ter izražanjem igre pri pujskih $\mathrm{v}$ času laktacije (pregl. 3; slika 3). To pomeni, da pujski, ki so sesali na prednjih seskih, niso bili bolj igrivi od tistih, ki so sesali na zadnjih seskih. Takšno predvidevanje temelji na rezultatih študije, ki jih je objavil Sundman (2011). Rezultati naše študije so pokazali, da je pujsek, ki je imel največjo odstavitveno telesno maso izražal tudi največ igre. Pujsek, ki je izražal največ igre, je bil po odstavitveni telesni masi najtežji, pujsek z najmanjšo aktivnostjo pri igri je imel za 2,10 kg manjšo odstavitveno telesno maso. Kljub tem podatkom, korelacija med igro skupaj in odstavitveno telesno maso ni bila statistično značilna (pregl. 3). Zanimivo je tudi to, da telesna masa pujskov ni bila odvisna od mesta sesanja oziroma od seska, ki ga je pujsek sesal (pregl. 3). Do enakih ugotovitev so prišli tudi pri opazovanju pujskov iz večjega števila gnezd (Skok in Škorjanc, 2013).

\section{SKLEPI}

Izsledki študije temeljijo na rezultatih uvodne raziskave, zato jih je potrebno jemati kot preliminarne informacije, ki služijo predvsem kot ideja za nadaljnjo bolj obsežno študijo. Rezultati kažejo, da pujski z višjim sesnim redom niso izražali več igre. Predvidevali smo, da pujski, ki sesajo na prednjih seskih, konzumirajo več mleka in imajo posledično tudi večji fitnes. Ugotovili smo tudi, da so lažji pujski izražali več gibalne igre in da je bila pogostost igre odvisna od dela dneva. Pujski so namreč opoldan izražali več igre skupaj kot zjutraj, najverjetneje zaradi hrupa ob krmljenju. S starostjo so pujski izražali več igre. Možna razlaga je v povezavi s pogostostjo sesanja in mirovanja, ki se proti koncu laktacije zmanjšujeta, medtem ko se aktivnost povečuje.

\section{$5 \quad$ VIRI}

Chaloupková, H., Illmann, G., Bartos, L., \& Spinká, M. (2007). The effect of pre-weaning housing on the play and agonistic behaviour of domestic pigs. Applied Animal Behaviour Science, 130, 25-34. doi:10.1016/j.applanim.2006.04.020

Dobao, M. T., Rodriganez, J., \& Silio, L. (1985). Choice of companions in social play in piglets. Applied Animal Behaviour Science, 13, 259-266. doi:10.1016/0168-1591(85)90049-8

Donaldson, T. M., Newberry, R. C., Špinka, M., \& Cloutier, S. (2002). Effects of early play experience on play behaviour of piglets after weaning. Applied Animal Behaviour Science, 79, 221-231. doi:10.1016/S0168-1591(02)00138-7

Dugatkin, L. A. (2009). Principles of animal behavior ( $2^{\text {nd }}$ ed.). New York, London: W.W. Norton \& Company.

Farhadi, N. (2013). Investigating the reward cycle for play in young pigs (M. Sc. Thesis). Swedish University of Agricultural Sciences, Uppsala.

Fraser, A. F., \& Broom, D. M. (1990). Farm animal behaviour and welfare ( $3^{\text {ed }}$ ed.). London: Baillibre Tindall.

Fraser, D. (1973). The nursing and suckling behaviour in pigs. The importance of stimulation of the anterior teats. British Veterinary Journal, 129, 324-336.

Held, S. D. E. \& Špinka, M. (2011). Animal play and animal 
welfare. Animal Behavior, 81, 891-899. doi:10.1016/j.anbehav.2011.01.007

Horrell, R. I., \& Bennett, J. (1981). Distruption of teat preferences and retardation of growth following cross-fostering of one-week-old. Animal Production, 33, 99-106. doi:10.1017/ S0003356100025253

Hrupka, B. J., Leibbrandt, V. D., Crenshaw, T. P., \& Benevenga, N. J. (1998). The effect of farrowing crate heat lamp location on sow and pig patterns of lying and pig survival. Journal of Animal Science, 76, 2995-3002. doi:10.2527/1998.76122995x

Hultman, P. (2012). Influence of providing objects to piglets before and after weaning on behaviour and weight gain (M. Sc. Thesis). Swedish University of Agricultural Sciences, Uppsala.

Lawrence, A. B., \& Appleby, M. C. (1996). Welfare of extensively farmed animals: principles and practice. Applied Animal Behaviour Science, 49, 1-8. doi:10.1016/01681591(95)00662-1

Mansbridge, S., \& Stewart, A. (2012). Assessing straw bedding intake in sows and growing pigs. Harper Adams University College

Newberry, R. C., \& Wood-Gush, D. G. M. (1986). Social relationships of piglets in a semi-natural enrivonrment. Animal Behavior, 34, 1311-1318. doi:10.1016/S00033472(86)80202-0

Newberry, R. C., Wood-Gush, D. G. M., \& Hall, J. W. (1988). Playful behaviour in piglets. Behavioural Processes, 17, 205216. doi:10.1016/0376-6357(88)90004-6

Petersen, V., Recen, B., \& Vestergaard, K. (1990). Behaviour of sow and piglets during farrowing under free-range conditions. Applied Animal Behaviour Science, 26, 169-179. doi:10.1016/0168-1591(90)90096-V

Rohde Parfet, K. A., \& Gonyou, H. W. (1991). Attraction of newborn piglets to auditory, visual, olfactory and tac- tile stimuli. Journal of Animal Science, 69, 125-133. doi:10.2527/1991.691125x

Rauw, W. M. (2013). A note on the consistency of a behavioral play marker in piglets. Journal of Animal Science and Biotechnology, 4(33), 6 str. doi:10.1186/2049-1891-4-33

Rosillon-Warnier, A., \& Paquay, R. (1984). Development and consequences of teat-order in piglets. Applied Animal Behaviour Science, 13, 47-58. doi:10.1016/0168-1591(84)900510

Skok, J., \& Škorjanc, D. (2013). Formation of teat order and estimation of piglets' distribution along the mammary complex using mid-domain effect (MDE) model. Applied Animal Behaviour Science, 144, 39-45. doi:10.1016/j.applanim.2012.11.014

Sundman, A. S. (2011). Personality in piglets: is there a difference in personality traits between pigs from different teat order positions (B. Sc. Thesis)? Sweden. Linkjöpings Universitet, Linkjöping.

Špinká, M., Newberry, R. C., \& Bekoff, M. (2001). Mammalian play: training for the unexpected. The Quarterly Review of Biology, 76, 141-168. doi:10.1086/393866

Thelen, E. (2000). Motor development as foundation and future of developmental psychology. International Journal of Behavioural Development, 24(4), 385-397. doi:10.1080/016502500750037937

Zupan, M., Janczak, A. M., Framstad, T., \& Zanella, A. J. 2012. The effect of biting tails and having tails bitten in pigs. Physiology \& Behaviour, 106, 638-644. doi:10.1016/j.physbeh.2012.04.025

Zupan, M., Rehn, T., Oliveira, D. \& Keeling L. J. (2016). Promoting positive states: the effect of early human handling on play and exploratory behaviour in pigs. Animal, 10, 135141. doi:10.1017/S1751731115001743 